\title{
Comparative Study of Competition Law between China and Pakistan with Special Reference to the Use of Evidences Submitted by Companies to Other Legal Proceedings
}

\author{
Nishan-E-Hyder Soomro ${ }^{1} \&$ Wang Yuhui ${ }^{1}$ \\ ${ }^{1}$ School of Law and Economic, Zhengzhou University, Zhengzhou, China \\ Correspondence: Wang Yuhui, Deputy Dean at School of Law and Economic, Zhengzhou University, Zhengzhou, \\ China. E-mail: 550805852@qq.com
}

Received: December 19, 2020

Accepted: January 22, $2021 \quad$ Online Published: January 28, 2021

doi:10.5539/jpl.v14n2p96

URL: https://doi.org/10.5539/jpl.v14n2p96

\begin{abstract}
The present study makes an attempt to make comparison between China and Pakistan with reference to Competition law. The research aims to find out that whether or not the evidences submitted by the companies during the course investigation can substantially be used in any other legal proceeding. As far as the methodology of this study is concerned, qualitative data analysis is used along with comparative legal method for analyzing "de lege lata" and "de lege ferenda" situation in scope of the solved topic. The study finds out that competition in Pakistan works same as China's AML since both forbids actions that play their negative role in reducing the competition like market dominance in the market. Therefore, the act encourages agreements that confine and restrict market dominance. Furthermore, methods and policies are stated by the law with reference to review of enquiries, acquisitions, mergers, penalties' imposition, leniency's grant along with other aspects of law enforcement. The evidences submitted by the companies during the course investigation can substantially be used in any other legal proceeding. The study concluded while contending that, however, AML in China and competition Act in Pakistan has provided both countries substantive and sound law, but there is need of strong and effective institutional implement which can provide a base for the evidences submitted by the companies during the course investigation to be substantially used in any other legal proceeding. Compliance is promoted by leniency through competition law along with incentives to prohibited arrangements. Qualitative research methodology has been applied to the following article.
\end{abstract}

Keywords: competition law, Pakistan, market, China, anti-monopoly law (AML), Competition Law Act 2010, legal proceeding

\section{Introduction}

There has more than 60 years of Pak-China friendship, since both countries extend their support to each other through thick and thin. In 1950, Pakistan was considered to be the 1st Muslim and 3rd non-communist country to recognize China between Pakistan and China, the diplomatic relations established in 1951. The friendship between Pakistan and China is known as everlasting and all weather. It is said that the friendship between both countries is higher than mountains and deeper than oceans. The relationship of both counties has emerged as a good model for neighboring countries' peaceful co-existence. Strong bilateral social, cultural and economic relationship has been enjoyed by Pakistan and China (Irshad, 2005). Both have always strived in order to promote stability, peace as well as economic prosperity in the region of south Asia. On 14th August, 1947, Pakistan came into being while China came into being on 1st of October; 1949. In 1950, China was recognized by Pakistan. The political relations of Pakistan and China are deep; however, both countries need to work more on their economic relationships. There is need of strengthening bilateral economic relations between both countries. At one time, Free Trade Agreement was known as a milestone to achieve this agreement was signed in 2007; however, CPEC (China-Pakistan economic corridor) is now regarded to be stepping stone in order to augment both countries' economic relations (GAO, 2003). People's National Congress adopted China's AML (Anti-Monopoly Law) went into effect on August 30, 2007 after debate and drafting's 14 years and on August 1, 2008. For market practices of the country, fundamental regulations are established by the AML and on different monopolistic practices of business, it sets restrictions with the purpose of development of free and open markets and solving main issues of antitrust (Harris, 2004). In global antitrust governance, crucial role is given by the AML which for China is a great leap forward. 
Basis of AML of China is in substantial part on established body of antitrust law in EU (European Union), Canada, and US (United States), the AML's provisions expose interesting uncertainties and doubts regarding some primary issues (Clarke, 2011). In AML, welfare standard applied is of particular interest to this paper. Doan and Stevens (2012) defined it as, "economic welfare is the standard concept used in economics to measure how well an industry performs" and "is a measure which aggregates the welfare (or surplus) of different groups in the economy." For example, consider a proposed merger which on welfare of producers and consumers would have different influences. In antitrust policy's context, basis for assessing how antitrust authorities consider various influences of welfare are provided by welfare standard (Doan, T., \& Stevens, 2012). Broadly speaking, there can be explanation of market economy as an economy where resources are collected and owned by individuals and their allocation is made possible via volunteer market which deals with supply and demand chain. People exchange monetary resources on volunteer basis in order to gain resources such as services and goods. Aforementioned behaviors are globally addressed by competition laws that eventually lead to reduction, restriction, prevention or distortion in competition (Gal, 2004). When there is no Competition law, there can be possibility of anti-competitive engagement practices in businesses for ousting their competitors instead of healthy competition on a legitimate basis. In Pakistan, consumer protection had not been the government's agenda before 1970s. In late1970s, it emerged in the shape of "Monopolies and Restrictive Trade Practices Act 1970" then competition ordinance was issues in 2007, which later turned out to be the Competition Act of 2010. They codified competition law as per global market standards (Kirkwood and Robert, 2008). Since then, some big changes and practices were witnessed in the commerce and business front. Under section 57, many rules were made, whose purpose was making the implementation of the Act possible. The government made an independent regulatory body for its execution, and this body was called "Competition Commission of Pakistan (CCP)" (Parakkal, 2011). The CCP is regarded as a quasi-judicial and quasi-regulatory body that plays an important role in ensuring the protection of consumer from anti competition forces and behaviors in the market. The research aims to make comparison of Pakistan's competition law and China's Anti-Monopoly law while exploring that the evidences submitted by the companies during the course investigation can substantially is used in any other legal proceedings.

\section{Literature Review}

The researchers have paid lot of attention to conduct research on China' AML and Pakistan's competition law separately, however, no attempt has ever been made to compare both countries' anti-monopoly and competition laws with special reference to the use of evidences submitted by Companies to other legal proceedings. Therefore, no existing literature on comparison of both countries anti-monopoly and competition laws with special reference to the use of evidences submitted by Companies to other legal proceedings is available. However, the literature produced over both countries' competition laws helps us understand similarities and differences. For instance, Simpson (2010) argued that during the legislative procedures for AML, many issues were debated heavily such as cartels' treatment and takeover by foreign enterprises, administrative monopoly's issue and policy towards SOEs. Some of the general features of AML must be noted before considering its details. There is similarity between AML and standard best-practice competition laws: on anti-competitive agreements, its general prohibitions, dominance's abuse, and anti-competitive mergers are in language that resembles with most OECD countries. Rather than North American, law's flavor is broadly European and especially Germanic. However, Competition Act (2010) describes competition processes' promotion and fortification as the basic feature of competition law in Pakistan. In competition law, "Equal opportunity field" is introduced for each and every player in the market, which plays an immensely significant part in terms of staying competitive. According to Wang (2008), for China, it can be said that a tremendous leap is the new AML, bringing it squarely into the antitrust and competition law's modern law. With input from U.S. law, it is based loosely on different European models, its general structure including four functional sections that: (1) prohibit agreements' various types unless they fall within some specific exemptions; (2) prohibit specific behavior categorized as dominant market position's abuse, providing framework for determination when there is existence of dominance; (3) launching a scheme of broad merger review; and (4) prohibit government administrative powers' abuses preventing competition. For some miscellaneous provisions and noncompliance, the law also sets penalties including one that refrain undefined intellectual property rights' "abuses". Healthy competition forces are given full chance in the market, which ultimately leads to the market's economic efficiency while protection consumers in Pakistan (GOP, 2010).

\subsection{Methodology}

Since it's a comparative legal research which help us comprehend legal order. The comparative law's essence is actually an act to compare one country's law with another country's while looking at differences and similirities. Therefore, the research is descriptive, comparative and analytical in nature. A legal comparative method is used for analyzing "de lege lata" and "de lege ferenda" situation in scope of the solved topic. As far as the research 
approach is concerned, qualitative data analysis is applied in order to conduct this research. Both primary and secondary sources are used to research the under examination topic.

\section{General Features of the Anti-Monopoly Law}

AML was formally placed on the legislative agenda in May 1994, and a group was formed by the government to draft an antimonopoly law. From the SAIC and the SETC (State Economic and Trade Commission), the group was drawn. In November 1999, the first complete law's draft appeared. Most of the features of AML were included in this draft whose effect occurred in August, 2008 (Poapongsakorn, 2002). The scope of AML covers the complete economy so it is comprehensive, although some provisions for exemptions and exclusions also exist which are similar to those in most OECD countries, though more extensive in context of tone, as discussed later. Sanctions, administrative processes and legal procedures are also established by the AML (Doan and Stevens, 2012). While the Chinese have generally sought to adopt best practice of world, it is also evident that the AML has "Chinese characteristics"; Chinese authorities have proclaimed this point and it is discussed below. Prohibition on the administrative powers' to restrict or eliminate competition is AML's unusual feature. The reason of this feature being unusual is that by businesses, most competition statutes are restricted to anti-competitive behavior. Similar to the EU and US competition laws, the expression of AML is in broad language (Owen et al., 2008). For Chinese laws to be uttered in general manner is customary. At some point, ambiguous language is incorporated deliberately by AML so that space for discretion is left and also for future development and unresolved policy questions are accommodated. It is intended that rulings, regulations and guidelines define AML. To comprehend it, guidelines need to be looked which accompany it and specific decisions as well as discussed in Section, a few guidelines have already been printed (Simpson, 2010)

\subsection{Objectives and General Principles}

General principles and objectives are set out by chapter one of the AML. Article 1 about the aim of law and 4th Article about the basis of founding and application of the competition rules are of particular importance to the comprehension of purposes of the law (Patel et al., 2011).

Article 1 states that: This law is enacted for the aim of refraining and preventing monopolistic behavior, protection of fair competition in the market, protecting the interests of social and consumer's public interest, enhancement of economic efficiency and promotion of the healthy growth and progress of the socialist market economy (Lapachi, 2002).

Article 4 states that: Competition rules are implemented and constituted by the State which accord with the socialist market economy, prefers macroeconomic control and regulation and promotes an open, unified, orderly and competitive market system. All these things are regulated and controlled (Kerber, 2007).

During the process of drafting, there was fine tuning of the wording and significant repositioning, which echoed disagreements and tensions about the aims of the law. Previous drafts of the law strongly emphasized purposes such as healthy growth and promotion of the socialist market economy; but this was included only as the last of objectives in the final version, though it is evident that it remains of significant importance (Kirkwood, J. B., \& Robert, 2008). Moreover, not like the previous drafts, the final version of draft includes reference to the efficiency's improvement, thereby to that extent bringing the Law in line with competition laws which are economic-based and approaches around the world (Parakkal, 2011).

\subsection{General Features of Competition Law in Pakistan}

In Pakistan, the basic features of competition law are the fortification and promotion of competition processes. "Equal opportunity field" is introduced competition law for each and every market player that plays an important role in staying competitive. While introducing CL the market is provided by Pakistan with "guidelines to play in the market" which plays an important role in protecting the competition processes in the market (Competition Act, 2010). The quest for effective as well as fair competition helps in terms of contributing to the growth of economic efficiency along with consumer development and welfare. The CL is based upon doctrine of 'restraint of trade' it can be traced back to English Common Law. For instance, sec 4 deals with market agreements of the anticompetitive under this act (Leslie, 2009). Moreover, a cartel is considered to be an agreement's product between different competitor's firms for making huge profit while assisting instead of competing each other in the market. Such agreements are greatly prohibited by Section 4 by stating that:

"No undertaking or association of undertakings shall enter into any agreement or, in the case of an association of undertakings, shall make a decision in respect of the production, supply, distribution, acquisition or control of goods or the provision of services which have the object or effect of preventing, restricting or reducing or distorting competition within the relevant market unless exempted under section 5 of this Ordinance" (Clarke, 2011). It can 
be considered one of many examples that show how the Act can be empowered for ensuring free and healthy competition for enhancing and maintaining economic efficiency (Leslie, 2009).

For the Act's efficient enforcement, certain powers are granted for Commission. Following is included in these powers:

- Data from any company, firm, venture and person etc.

- Seek to the support of any authority figure, individual or any federal agency for discharging its functions and duties.

- Enter along with examining premises by exhibiting anti-competitive practices as well as exercises.

- Inflict penalty or a fine of approximately $10 \%$ of the turnover of former financial year in case of defiance, penalty can be imposed.

- Proper direction might be given by the commission for reviving competition in market.

In short, it can be said that competition in Pakistan works same as China's AML since both forbids actions that play their negative role in reducing the competition like market dominance in the market. Therefore, the act encourages agreements that confine and restrict market dominance. Furthermore, methods and policies are stated by the law with reference to review of enquiries, acquisitions, mergers, penalties' imposition, leniency's grant along with other aspects of law enforcement.

\subsection{Ruibang v. Johnson \& Johnson Cases}

Under AML Article 14.2, this is the vertical monopoly agreement's first judgment and judicial case, and also the first case in which judgment was overruled by the High Court in favor of the defendant which is made by the Intermediate court (Wang, 2002).

The case's fact can be viewed as straight forward as well as simple. In this case, the plaintiff, ("Ruibang"), is known as Johnson \& Johnson's authorized distributor (Shanghai) and (China) (Wen, 2008). J\&J was sued by Ruibang sued J\&J in shanghai New district court. The partial withdraw of J\&J from the distributorship of Ruibang. Take off the distributor deposit of Ruibang while refusing eventually to supply by giving this reason that an agreement was breached by Ruibang since it sets lowest resell prices in the unauthorized territories (Wang, 2002).

In AML 14.2 Article, Similar judicial analysis was made by both courts of appeal and instance; a judgment was made by Shanghai New District Court on 18 May, 2012 (Judgment 2010 Hu Yi Zhong Min Wu Zhi Chi Zi No 169) in favor of J\&J on plaintiff's insufficient evidence's ground. Ruibang requested to the Shanghai High Court and also submitted a detailed and professional affidavit which was made by a professor of China Foreign Economic and Trade University, and as an answer or fight back a broad and knowledgeable affidavit was submitted by J\&J which was made by a professor of Shanghai Finance and Economic University (Edward, 2013). On 1 August, 2013, a conclusive judgment was made by the Shanghai High Court Hu Min San (Zhi) Zhong Zi No 63 that overruled the judgment made by the Shanghai Pudong New District Court ruling that AML Article 14.2 had been violated by $\mathrm{J} \& \mathrm{~J}$ and be liable for the damages which are judged.

Some observations have been offered by this case and some of its final judgments:

- The vertical agreement is subject to "rule of reason" under the AML, namely, it is not "per se illegal" but very likely "per se challengeable" and "effect" test is compulsory so that it can be assessed if a AML is breached by vertical agreement or not.

- In the "effect" test, four elements: (1) market position, (2) sufficient competition, (3) effects of competition promotion and (4) Motivation.

- The implication of the doctrine of maxim "semper necessitas probandi incumbit ei qui agit" in the AML private enforcement case (Farmer, 2013).

In these articles, various goals of policy are involved. China has never committed to adopt capitalist economy along with production assets' private ownership. It has never made such commitment (Wang, 2008). In the same context, including the goal of "promoting the healthy development of the socialist market economy" in Article 1 as well as in Article 4 the reference to the "socialist market economy" has underlined that there is competent acceptance of orthodox Western goals of efficiency, fairness, and competition. In underlying principles of law, this introduces a noteworthy degree of ambiguity and conflict and it leaves space for avoidance of widely accepted competition rules, particularly with reference to SOEs treatment as well as administrative monopoly, which are considered to be the significant areas of the competition policy in China (Blair and Sokol, 2013).

In Article 5, in development of large Chinese businesses, there can be seen a greater indication of national interests, 
which delivers that:

Through voluntary alliance and fair competition, undertakings may concentrate themselves in accordance to law, improve competitiveness and also make expansion in scope of operations of business (Farmer, 2013)

There are various ways in which Article 5 can be read: in any economy, business concentration can occur including acquisitions and mergers and it is simply an acknowledgement. One can also take all this as a signal that there would not be strict application of the AML merger control rules, especially to transactions which are introduced and progressed by national champions and also transactions which are purely domestic (Blair and Sokol, 2013). In this reference, it is significant to be noted that in 2004, SAIC issued a report while calling for stronger and effective competition law for protecting against anti competition strategies of large foreign companies. Foreign companies may face some closer enforcement examination; a strong position is taken by anti-monopoly enforcement authority with reference to putting pressures on foreign companies in China (Naughton, 2007).

\section{Limits of the AML}

\subsection{Special Treatement for SOEs}

Legitimate operating actions of industries which are dominated by the "state-owned economy" which are beneficial to the national security or Chinese national economy or both and of those under-takings with statutory rights of exclusive sales or operations shall be protected by state, as claimed by the Article number 7 of the AML. It is further stated by Article 7 that to safeguard the consumers' interests and also for promotion of technological progress, state will control and manage these prices and operations of undertakings (Lin, P., \& Zhao, 2012). There is requirement of these undertakings to function in good faith and also for in accordance with the law, and to accept public supervision, and are banned from using their controlling or exclusive positions to damage consumers.

It is believed by Huang (2008) that "article 7 is a compromise between industrial policy and competition law and there are probably three interpretations: one of these is that for SOEs, there is almost complete exception." To SOEs, There is full application at the other extreme. He further argued that "An inter-mediate position is that in most respects, the law applies to SOEs; but where there are operating activities which are explicit and state required which can run afoul of the competition law's application, they are protected" (Huang, 2008). In OECD economies, such conditions arise sometimes, where to comply with competition law, a utility is required but not to that extent in which it cannot execute government requirements or statutory that could fight with these laws (for example, pricing that to particular customer's classes provide subsidies). One of the classical examples is if abuse of dominance charge is protected by SOE on the grounds that retaining dominant status is obligatory in order to meet social obligations such as a loss making cross-subsidy (Lin and Zhao, 2012).

The SOEs treatment doesn't differentiate as much from what is observed in OECD economies as they firstly may appear. There has been state-owned history in many such economies, vertically combined monopolies in public utilities areas for example communication, energy and transport. In these areas, the competition law's application is very limited. No competitors are there of pure monopolist with which they can merge or combine with or to exercise dominance against (Wang, 2008). Set of steps beyond the competition's law's scope is required so that competition can be introduced- such as entry's removal, investment and trade barriers; the promotion of international and interregional competition; vertical and horizontal disaggregation; "essential facilities" laws; and laws of competitive neutrality and competition law becomes relevant after that, usually highly relevant (Lin and Zhao, 2012).

\subsection{AML Exclusion for the Agricultural Sector}

Agriculture is involved in the only sectoral exclusion from AML. For agricultural producers, statutory exclusion is provided by the AML by stating that it will not be applicable to concerted actions and alliances among rural economic firms and agricultural producers in operational activities such as the processing, transportation, production, sales and agricultural products' storage (AML, Art. 56). In OECD countries, this is not uncommon (Wang, 2009).

Two new agencies are created by the law: "AMC" the Anti-Monopoly Commission, a body of policy under the State Council, in Chinese government, the highest-ranking executive body and the "AMEA" (Anti-monopoly Enforcement Authority), which will be responsible for law's day to day implementation. Offices from at least three previously existing agencies will be included in the AMEA: SAIC (the State Administration for Industry and Commerce), the NDRC (National Development and Reform Commission), and the Ministry many factors of the law remain to be explained by thorough execution of guidelines and regulations and actual enforcement experience in both administrative courts and agencies (Bergh and Faure, 2011). From this writing, there is only one such executing regulation which has been broadcasted: for concentrations of undertakings ("Regulations"), the 
Regulation on Notification Threshold for Concentrations, which for necessary filing of notifications of proposed acquisitions and mergers, sets forth thresholds (Berry, 2005). On its face, there is larger consistency between the law and the other large jurisdictions' antitrust laws, but some of the provisions show that uniquely concepts of Chinese policy and law may bear the law's explanation and implementation.

\subsection{Administrative Enforcement under AML}

It is evident in the administrative enforcement, NRDC is suitable to apply the doctrine of "illegal per se rule" directly to the first category (for example, AML Articles 13, 14 and 17(1) due to the low costs and issues and also proceeding is easy to apply the "per se rule" in the AML's administrative enforcement. Recent four cases have evidenced that during January to August 2013, NRDC announced, because neither analysis nor examination on the "reason" or "reasonable cause" had ever been made to the exclusion or restriction effects of competition by the conducts of alleged monopolists (Farmer, 2013). Although many questions have been raised to it, it appears that NRDC follows and also carry on the tactics and scheme that in US were adopted in earlier stage of the enactment of Sherman Act at the turn of $19^{\text {th }}$ century and $20^{\text {th }}$ also to put a direct "illegal per se" influence to Article number 13 and 14 of the AML (Han, 2004). This makes crucial sense as it draws boundary line as between the "illegal per se" agreements and conducts and those agreements and conducts with "reasonable cause". In a summary, there are some issues which if Supreme Court clearly doesn't interpret by further judicial rulings and opinions, then they will remain open issue in China's anti-monopoly legal system. These issues include whether Article 13 and 14's unconditional prohibitions would equally have resembling nature of "illegal per se" or not and also that how to differentiate Article 13 and 14 from "reasonable cause" in Article 17(2) to (6) (Huang, 2008). No precedent case law exists. Academic researchers, practitioners of law study the judgments specifically those judicial or methodological opinions made by Supreme court or High court in the landmark cases. They are studied indirectly as guideline invoked by other courts in succeeding cases (Wang, 2009).

\subsection{Huawei v. IDC cases}

Guangdong high court made two judgments which are published and both these contain all sensitive data and information which are redacted. Both of these cases are mostly treated as a single united case by Huawei against ICS although they are two separate cases and China courts have also apprised them as one of the vest AML cases by then. People consider this is very controversial (Liu and Y.Qiao, 2012). We can consider the following:

- There is extreme lack in case 857, Judgment 305: (1) judicial analysis for support and justification of the Chinese law's ruling on choices and China court's forum jurisdiction in a royalty rate case which is dependent on the interpretation of royalty policy and also on the rules and regulations of the (ETSI) European Telecommunications Standards Institute which is managed and governed by French law;

- Under the current law in China, legal grounds on court's right in determination of a non-tort (or infringement), contrast's non-breach but a pure commercial term

- China, a petition was filed by IDC on April 14, 2014 for purpose of retrial and also wishing this judgement's dismissal or at least a higher royalty rate which would also be market based. Currently, it is pending with China Supreme Court (Yang, 2002).

- In case 858, Judgement 306, this is an "abuse of intellectual property right" case under AML Article 55 than an "abuse of dominant market position" case under AML Article 17, initial judgment was upheld by Guangdong High Court so that IDC can be judged and RMB20 million can also be compensated. Two AML aspects are covered by this final Ruling both of which are leading edge along with being jurisprudence. "Extraterritoriality" is the first aspect under AML $2^{\text {nd }}$ Article, while second aspect is that the Ruling appears to use the "abuse of dominant market position" under AML 17 $17^{\text {th }}$ article for the "abuse of intellectual property right" case under $55^{\text {th }}$ AML Article (Xinhua News, 2007).

\subsection{Administrative Settlement of Cases under Pakistan's Competition Law}

When it comes to cases' administrative settlement, 2007 competition commission notes that after initiating proceedings, the CCP accept commitment from undertaking which provides remedy for Act violation, but CCP is not bound to accept commitment. But it doesn't mean no violation has been made if CCP accepts any commitment. It is worth mentioning that even if commitment is made, decision regarding commitment can still be revoked by CCP if it is found that commitment has been breached under CCP rules. An important feature is formed by the cases' administrative settlement, which plays an important role in providing to "Consent Orders", In this case all parties get agreed to settle any part or all proceedings. The consent orders are made by CCP accordingly.

While keeping in view both AML and competition law, it can be argued that the evidences submitted by the companies during the course of investigation can substantially be used in any other legal proceeding, however, 
enquiries can be conducted by the regulatory authorities on the recipient of complaints either from a consumer's registered association or an undertaking. Additionally it is also worth noting that for suo moto action, the term 'Shall' is used whereas third party used the term 'May'.

For enforcing substantive provisions, essential tools have been given by Act for forcible leniency and entry. It is said that "Forcible entry becomes necessary when an undertaking refuses to let properly authorized officers of the Commission to enter and search premises with a view to gather material that may be relevant for proving and enforcing the provision of the Act. In order to protect that the provision of forcible entry is not abused, the Act provides that an order authorizing an officer(s) to forcibly enter and search premises has to be signed by two members of the Commission, and the officer so authorized shall not use his power with vexatious, excessive or with mala fide intent." For leniency, an undertaking is provided by Section 39 while making true and full disclosure of an agreement for a party. Compliance is promoted by leniency through competition law along with incentives to prohibited arrangements. The dilemma of prisoner for cartelists is created by leniency, which plays an immensely significant role in terms of breaking the cartels.

\section{Conclusion}

To sum up in a nutshell it can be concluded that the evidences submitted by the companies during the course investigation can substantially be used in any other legal proceeding. It can also be contended that competition in Pakistan operates same like China's AML since both play their role in terms of forbidding actions, which negatively influence in order to reduce the competition like market dominance. Therefore, the act encourages agreements that confine and restrict market dominance. Furthermore, methods and policies are stated by the law with reference to review of enquiries, acquisitions, mergers, penalties' imposition, leniency's grant along with other aspects of law enforcement. However, AML in China and competition Act in Pakistan has provided both countries substantive and sound law, but there is need of strong and effective institutional implement which can provide a base for the evidences submitted by the companies during the course investigation to be substantially used in any other legal proceeding. Compliance is promoted by leniency through competition law along with incentives to prohibited arrangements.

\section{References}

Berry, J. A. (2005). Anti-Monopoly Law in China: A Socialist Market Economy Wrestles with Its Antitrust Regime. International Law and Management Review, 2, 144.

Blair, R. D., \& Sokol, D. D. (2013). Welfare Standards in U.S. and E.U. Antitrust Enforcement. Fordham Law Review, 81, 118. https://doi.org/10.2139/ssrn.2195938

Clarke, G. R. G. (2011). Competition Policy and Innovation in Developing Countries: Empirical Evidence. International Journal of Economics and Finance, 3(3), 38-49. https://doi.org/10.5539/ijef.v3n3p38

Competition Act, 2010 (PAK) (Act XIX of 2010, Published in the Gazette of Pakistan, Extraordinary on 13 October 2010) accessed 4 January 2012.

Doan, T., \& Stevens, P. (2012). Evolution of Competition in Vietnam Industries over the Recent Economic Transition. Economics: The Open-Access, Open-Assessment E-Journal, 6(19), 2012-2019. https://doi.org/10.5018/economics-ejournal.ja.2012-19

Edward, E. (2013). The Chinese Anti-Monopoly Law, New Developments and Empirical Evidence.

Farmer. (2013). Recent Developments in Regulation and Competition Policy in China: Trends in Private Civil Litigation. In M. Faure, \& X. Zhang (Eds.), The Chinese Antimonopoly Law, New Developments and Empirical Evidence. Edward Elgar.

Gal, M. S. (2004). The Ecology of Antitrust Preconditions for Competition Law Enforcement in Developing Countries. In Competition, Competitiveness Development. UNCTAD.

Gao, B. (2013). October. From Maritime Asia to Continental Asia: China's Responses to the Challenge of the Trans-Pacific Partnership. In Conference Paper presented at; The TransPacific Partnership and Taiwan's Future Development Strategy, Stanford, CA (Vol. 11).

Government of Pakistan, 'Poverty Reduction and Strategy Paper - II'. (Country Report 10/183, IMF 2010). Retrieved December 23, 2011, from http://www.imf.org/external/pubs/ft/scr/2010/cr10183.pdf

Han. (2004). The Opportunity to Establish a Competition System - Foreign M\&A as the External Pressure for the AML. International Trade, (1), 45.

Harris, H. S. (2006). The Making of an Antitrust Law: The Pending Anti-Monopoly Law of the People's Republic 
of China. Chicago Journal of International Law, 7(1), 169-229.

Huang, Y. (2008). Pursuing the second best: The history, momentum, and remaining issues of China's antimonopoly law. Antitrust Law Journal, 75(1), 117-131.

Irshad, M. S. (2015). One Belt and One Road: Dose China-Pakistan Economic Corridor Benefit for Pakistan's Economy? Journal of Economics and Sustainable Development, 6(24).

Kerber, W. (2007). Should Competition law promote efficiency? Some Reflections of an economist on the normative foundations of competition law. In Economic (pp. 3-4). Edward Elgar Publishing.

Kirkwood, J. B., \& Robert, H. (2008). The Fundamental Goal of Antitrust: Protecting Consumers, Not Increasing Efficiency. Notre Dame Law Review, 83, 191-244.

Lapachi, K. (2002). An examination of the present competition law of Georgia using Pittman's criteria. Antitrust Bulletin, 47(1), 187-215. https://doi.org/10.1177/0003603X0204700108

Leslie, C. R. (2009), Antitrust and Patent Law as Component Parts of Innovation Policy. Journal of Corporation Law, 34(4), 1259-1289

Lin, P., \& Zhao, J. (2012) Merger control policy under China's anti-monopoly law. Review of Industrial Organization. https://doi.org/10.1007/s11151-012-9345-9

Liu, Z., \& Qiao, Y. (2012). Abuse of Market Dominance Under China's 2007 Anti-Monopoly Law: A Preliminary Assessment. Review of Industrial Organization, 78. https://doi.org/10.1007/s11151-012-9346-8

Naughton, B. (2007). The Chinese economy: Transitions and growth. Cambridge: MIT Press

Owen, B. M., Sun, S., \& Zheng, W. (2008). China's Competition Policy Reforms: The Anti-monopoly Law and Beyond. Antitrust Law Journal, 75(1), 231-265.

Parakkal, R. (2011). Political characteristics and competition law enactment: A cross-country empirical analysis. The Antitrust bulletin, 56, 609-629. https://doi.org/10.1177/0003603X1105600305

Patel, A., Panda, A., Deo, A., Khettry, S., \& Mathew, S. P. (2011). Intellectual Property Law \& Competition Law. Journal of International Commercial Law and Technology, 6(2), 120-130.

Poapongsakorn, N. (2002). The New Competition Law in Thailand: Lessons for Institution Building. Review of Industrial Organization, 21(2), 185-204. http://dx.doi.org/10.1023/A:1019681612535

Simpson, B. P. (2010). Two Theories of Monopoly and Competition: Implications and Applications. The Journal of Applied Business and Economics, 7(4), 139-151.

Van den Bergh, R., \& Faure, M. (2011). Critical Issues in the Enforcement of the AntiMonopoly Law in China: A Law and Economics Perspective. In M. Faure, \& X. Zhang (Eds.), Competition Policy and Regulation, Recent Developments in China, the US and Europe (pp. 54-72). Edward Elgar.

Wang, X. (2002). The prospect of antimonopoly legislation in China. Washington University Global Studies Law Review, 201-232.

Wang, X. (2009). The new Chinese anti-monopoly law: A survey of a work in progress. The Antitrust Bulletin, 54(3), 579-619. https://doi.org/10.1177/0003603X0905400303

Wen, X. (2008). Market dominance by China's public utility enterprises. Antitrust Law Journal, 75(1), 151-171.

Xinhua News. (2007). Business Week: China Makes Remarkable Progress in Civil Law Making. supra n. 63.

Yang, J. (2002). Market Power in China: Manifestations, Eff ects and Legislation. Review of Industrial Organization, 21, 170-171.

\section{Copyrights}

Copyright for this article is retained by the author(s), with first publication rights granted to the journal.

This is an open-access article distributed under the terms and conditions of the Creative Commons Attribution license (http://creativecommons.org/licenses/by/4.0/). 